\title{
EFFECT OF DIETARY PROBIOTIC AND SEX ON PRODUCTIVE PERFORMANCE, NUTRIENT DIGESTIBILITY, CARCASS CRITERIA, BLOOD BIOCHEMISTRY OF GROWING NEW ZEALAND WHITE RABBITS
}

\author{
F.S.O. Elkhateeb, Z.S.H. Ismail, and A.A.A. Abdel-Wareth* \\ Animal and Poultry Production Department, Faculty of Agriculture, South Valley University, Egypt \\ * Corresponding author: Email: a.wareth@agr.svu.edu.eg
}

Received: $14 / 2 / 2018$

\section{SUMMARY}

The experiment was conducted to investigate the effect of dietary probiotic levels and sex on growth performance, nutrient digestibility, carcass criteria, blood biochemistry and meat quality of growing rabbits. A total of sixty four growing male and female New Zealand White rabbits (45 days old), were assigned to four experimental diets including added probiotic at 0, 150, 300 and $450 \mathrm{~m} \mathrm{~g} / \mathrm{kg}$, respectively, for six weeks. Each treatment had 16 replicates (50\% males and 50\% females). Sex of rabbits did not affect the body weight gain, feed intake, feed conversion ratio and nutrient digestibility during the experimental periods. Body weight gain increased and feed conversion ratio decreased significantly from 0 to $450 \mathrm{mg} / \mathrm{kg}$ during the period from 0 to 2 , 4 to 6 and 0 to 6 weeks of age, respectively. Feed intake exhibited a noticeable significance $(p<0.05)$ in interaction between probiotic treatment levels and sex in the period from 4 to 6 weeks only. Supplementation of probiotic improved the nutrient digestibility during the experimental period. Cecum and gut weights increased significantly from 150 to $450 \mathrm{mg} / \mathrm{kg}$. Interestingly, serum glucose and cholesterol levels showed a significant decrease $(P<0.001)$ among probiotic treatments in comparison with the control group. Serum total protein, testosterone, estrogen, progesterone and tri-iodothyronine showed a higher significance $(P<0.001)$ in the probiotic levels compared to control group, however thyroxin showed no significant increase or decrease where the tested groups exhibits nearly the normal levels. It could be concluded that supplementation of probiotics to the rabbits diet improved nutrient digestibility and blood glucose, cholesterol and hormones level without any reflection of probiotics on body weight and carcass criteria including carcass weight, hot carcass, liver, kidney, spleen, lungs, heart and head on either male or female growing rabbits.

Keyword: Probiotics, performance, nutrient digestibility, some serum biochemical profile, meat quality, rabbits

\section{INTRODUCTION}

Rabbit production in Egypt has developed rapidly, most notably to meet an increased demand of fresh meat for human consumption as well as a source of extra income for families or small farmers in Egypt (Abdel-Wareth et al., 2015). Rabbit meat is characterised by convenient sources of palatable and nutritious meat, high in protein, and contain low fat and cholesterol, hence its suitability as special diet (Owen, 1981). However, its production may be limited by inadequate nutrient diet contents (Chantalakhana, 1990). Consequent to the prohibition of in-feed use of antibiotics and other chemical growth promoters in many parts of the world, there has been an increased interest in alternative approaches, which include herbs, probiotics, prebiotics and acidifiers, which were successfully used by many investigators (Tokic et al., 2007; Yang et al., 2007; Awaad, et al., 2011; Abdel-Wareth et al., 2012; Abdel-Wareth and Lohakare, 2014; and Abdel-Wareth, 2016). Therefore, probiotics which are mono-or mixed culture of living microorganisms, induce beneficial effects on the host by improving the properties of the indigenous microflora (Ghadban, 2002). Biotechnological treatments including either the direct use of microorganisms or microbial enzyme to improve the nutrient digestibility of feed ingredients (Shaiful, 1992). Inclusion of probiotics in animal feed has been shown to improve the growth performance, nutrient digestibility and feed efficiency of animals (Martin et al., 1989; Santin et al., 2001; Ezema and Eze, 2012). Bioactive yeast secretes enzymes which increase digestibility and efficiency of feed utilization (Ozcan, 2001). Serum biochemical analysis is important indicators of physiological, nutritional, pathological status and the health status of animal (Archetti et al., 2008 and Melillo, 2007).

Probiotics have been reported to have favourable effects on performance, beneficial effects upon supplementation to animals feed since it has many values such as enhancement of the immune system, antimicrobial effects gut functions cholesterol concentrations, management of diabetes and prevention of osteoporosis, improved nutrition through the enhanced breakdown of nutrients and their absorption through the intestinal walls, cleansing of the blood stream by making it freer of toxins and prevention of infection by harmful bacteria (Rautray et al., 2011). 
Recent research on the molecular biology and genomics of Lactobacillus has focused on the interaction with the immune system, anti-cancer potential, and potential as a biotherapeutic agent in cases of antibiotic-associated diarrhoea, travellers' diarrhoea, paediatric diarrhoea, inflammatory bowel disease and irritable bowel syndrome and ability of modifying the gut microflora (Ghadban, 2002). The mechanism of action of probiotics has not been elucidated, but might include reduction of toxin production, stimulation of enzyme production, production of some vitamins or antimicrobial substances, competition for adhesion to epithelial cells and increased resistance to colonization, stimulation of the immune system of the host and reduction of stress in rabbits (Falcão-e-Cunha et al., 2007). Inclusion of probiotic feed additives in feed may enhance reproductive performance of rabbits. Therefore, the objective of this study was to evaluate the effect of dietary probiotics levels and sex on growth performance, nutrient digestibility, carcass characteristics, serum biochemical profile, and meat quality of growing rabbits.

\section{MATERIALS AND METHODS}

\section{Experimental animals, design and management:}

A total of sixty four, 45-days-old, New Zealand rabbits (50\% males and 50\% females) were randomly allocated into four treatment groups of 16 rabbits each $(n=16)$. The rabbits of the control group were fed ad libitum from 45 to 87 days of age; the other three groups received the control diet supplemented with $150 \mathrm{~g} / \mathrm{kg}, 300 \mathrm{~g} / \mathrm{kg}$ and $450 \mathrm{~g} / \mathrm{kg}$ probiotics mix (1:1 Bacillus subtilis and Lactobacillus acidophilus), respectively.
Rabbits were individually reared in cages of galvanised wire net (width $\times$ length $\times$ height: $50 \mathrm{~cm}$ $\times 60 \mathrm{~cm} \times 40 \mathrm{~cm}$ ), equipped with fresh tap water, which was available for ad libitum intake via stainless steel nipples located inside each cage. Ambient temperature was maintained at $22^{\circ} \mathrm{C}$ with a $12 \mathrm{~h}$ light/dark cycle. During the total experimental period of 6 weeks (wks). Rabbits were housed under the same managerial, hygienic and environmental conditions, and throughout the trial, the rabbits were handled according to the principles of care for experimental animals (Lebas et al., 1984), and the experiment was approved by the Committee of Ethics for the Animal and Poultry Production Department of the South Valley University, Egypt.

The rabbits were subjected to regular inspections for health and body conditions. The assessments of body conditions were carried out by touching the ribs, pelvis and spine of the rabbits (Abdel-Wareth et al., 2015).

Ingredients and chemical composition of the experimental diets are presented in Table (1). Animals of all treatments received the same diet that was formulated to meet the standard nutritional requirements of growing meat-type rabbits (Lebas, 2004). The mean gross energy and crude protein concentrations were $18.2 \mathrm{MJ} / \mathrm{kg}$ and $170 \mathrm{~g} / \mathrm{kg}$, respectively. Individual feed intake was recorded weekly at 8:00am. Each rabbit was weighed weekly at the same day at 7:00 am. Feed conversion ratio (FCR) was calculated by dividing daily feed consumption by average daily body weight gain (BWG). Mortality rate was recorded as it occurred and any signs of diarrhea were documented daily.

Table 1. Ingredients and chemical composition of the experimental diets of growing Nzw white rabbits

\begin{tabular}{lllll}
\hline Ingredients, g/kg & Control & $150 \%$ Pro & $300 \%$ Pro & $450 \%$ Pro \\
\hline Yellow maize grain & 320.0 & 320.0 & 320.0 & 320.0 \\
Wheat bran & 200.0 & 200.0 & 200.0 & 200.0 \\
Soybean meal (44\% CP) & 180.0 & 180.0 & 180.0 & 180.0 \\
Wheat straw & 120.0 & 120.0 & 120.0 & 120.0 \\
Lucerne hay & 50.0 & 50.0 & 50.0 & 50.0 \\
Rice bran & 50.0 & 50.0 & 50.0 & 50.0 \\
Linseed straw & 28.0 & 28.0 & 28.0 & 28.0 \\
Sunflower meal & 25.0 & 25.0 & 25.0 & 25.0 \\
Lime stone & 20.0 & 20.0 & 20.0 & 20.0 \\
Sodium chloride & 3.0 & 3.0 & 3.0 & 3.0 \\
Vitamin-mineral mix ${ }^{\mathrm{a}}$ & 3.0 & 3.0 & 3.0 & 3.0 \\
DL-Methionine & 1.0 & 1.0 & 1.0 & 1.0 \\
Chemical composition analysed, g/kg & & & 91.0 \\
Dry matter & 914.0 & 915.0 & 914.0 & 915.0 \\
Ash & 98.20 & 98.23 & 98.26 & 98.28 \\
Crude protein & 18.6 & 18.6 & 18.8 & 19.0 \\
Crude fiber & 11.9 & 11.9 & 11.9 & 11.8 \\
Ether extract & 29.2 & 29.1 & 29.4 & 29.6 \\
Gross energy, MJ/kg & 18.24 & 18.26 & 18.28 & 18.40 \\
\hline
\end{tabular}

Notes: §Vitamin and mineral premix provided per kg of diet: vitamin A, 10.000 IU; vitamin $\mathrm{D}_{3}$, $900 \mathrm{IU}$; vitamin E, $50 \mathrm{mg}$; vitamin K, $2 \mathrm{mg}$; vitamin $\mathrm{B}_{1}, 2 \mathrm{mg}$; folic acid, $5 \mathrm{mg}$; pantothenic acid, $20 \mathrm{mg}$; vitamin $\mathrm{B}_{6}, 2 \mathrm{mg}$; choline, $1.2 \mathrm{~g}$; vitamin $\mathrm{B}_{12}$, $10 \mu \mathrm{g}$; niacin, $50 \mathrm{mg}$; biotin, $0.2 \mathrm{mg}$; Cu, $0.1 \mathrm{mg}$; Fe, $75 \mathrm{mg}$; Mn, $8.5 \mathrm{mg} ; \mathrm{Zn}, 70 \mathrm{mg}$ 


\section{Digestibility trial:}

At the end of the experiment, a digestibility trial was conducted in the last three days where the rabbits were individually housed in metabolic cages which allowed separation of faeces and urine. Every day at the same time, the animals were fed the pelleted experimental diet and always had free access to clean drinking water. Feed residues and faeces were collected every day and weighed to the nearest one $g$ using an analytical scale. Faeces were stored frozen, and after thawing, samples were dried and ground. The samples prepared in this way were analysed for chemical composition and energy value to calculate digestibility coefficients of nutrients and energy. The digestibility coefficient (DC) of nutrients was calculated according to the following equation:

$\mathrm{DC}[\%]=[(\mathrm{t}-\mathrm{f}) / \mathrm{t}] 100$;

Where, $(\mathrm{t})$ is expressing the nutrient intake during the collection period $[\mathrm{g}]$, and (f) express the amount of nutrient excreted in faeces $[\mathrm{g}]$.

\section{Chemical analysis:}

The diet and faces were analyzed for estimation of moisture by oven drying (930.15), ash by incineration (942.05), protein by Kjeldahl (984.13), and ether extract by Soxhlet fat analysis (920.39), Crude Fiber was determined by the Weende method as described by the AOAC International (2006). Gross energy was determined by Parr adiabatic bomb (Moline, IL, USA).

\section{Carcass measurements and meat quality:}

Six representative rabbits from each treatment were selected for similar final body weight (slaughter weight) and sacrificed at termination of the experimental period of 87 days of age. The sacrificed rabbits were bled and then the skin, genitals, head, urinary bladder, gastrointestinal tract and the distal part of legs were removed. Head and full gastrointestinal tract were weighed and expressed as percentage of slaughter weight. Also, the length of full gastrointestinal tract was measured. Carcasses, with liver, heart, spleen, lungs, kidneys, as well as perineal and scapular fat were weighed and calculated as percent of hot carcass. Carcass yield was calculated as per the following:

Carcass yield $[\%]=($ Hot carcass weight $[\mathrm{g}] /$ Body weight $[\mathrm{g}] * 100$.

The ratio of the internal organs including carcass weight, liver, kidney, spleen, lungs and heart (each separately) to the hot carcass weight was calculated as required.

To evaluate meat quality Ultimate $\mathrm{pH}(\mathrm{pHu})$ was measured at $24 \mathrm{~h}$ post mortem with a Knick digital pH meter (Broadly Corp., Santa Ana, CA, USA) after homogenization of raw muscles $(5 \mathrm{~g})$ with iodoacetate (Korkeala et al., 1984). To evaluate cooking loss, muscle samples of about $5 \mathrm{~g}$ were placed in an open aluminum pans and cooked in an electric oven (preheated at $200{ }^{\circ} \mathrm{C}$ ) for $15 \mathrm{~min}$ to an internal temperature of $80{ }^{\circ} \mathrm{C}$ (Cyril et al., 1996). Cooking loss was estimated as the difference between the weight of the cooked samples (cooled for $30 \mathrm{~min}$ at $15^{\circ} \mathrm{C}$ ) and the weight of the raw samples expressed in percentage of the raw sample. The Water Holding Capacity (WHC) was estimated by centrifuging $5 \mathrm{~g}$ of muscle placed on tissue paper inside a tube, for $4 \mathrm{~min}$ at $1.500 \mathrm{x} \mathrm{g}$ (Nakamura and Katoh, 1985). The water remaining after centrifugation was quantified by drying the samples at $70{ }^{\circ} \mathrm{C}$ overnight. The WHC was calculated as follows: (weight after centrifugation - weight after drying) x 100/initial weight.

\section{Blood sampling and laboratory analyses:}

At the end of the experimental period (87 days age), blood samples of growing rabbits (6 rabbits within each experimental group) were collected during slaughter. Blood samples were kept in dry clean centrifuge tubes. After the serum was separated naturally, it was centrifuged for $10 \mathrm{~min}(3000 \mathrm{rpm})$ at room temperature. Serum was collected in tubes and stored at $-20^{\circ} \mathrm{C}$ until further analysis. Serum glucose, total cholesterol and total proteins were measured spectrophotometrically by using commercial kits (Spectrum chemical company, Obour City - Cairo, Egypt). Serum total testosterone was assayed colorimetrically by a spectrophotometer according to the method of Ismail et al. (1986), using a competitive chemiluminescent enzyme immunoassay kit. Serum progesterone and estradiol were determined using method reported by Burtis and Ashwood (1994) using a competitive chemiluminescent enzyme immunoassay kit. Serum thyroxine (T4) and tri-iodothyronine (T3) were measured according to the method of Witherspoon and Shuler (1984) and Felig et al. (1987), respectively, using chemiluminescent microparticle immunoassay (CMIA) kit.

\section{Statistical analysis:}

Experimental data were analyzed as a randomized complete block design, with $2 \times 4$ factorial arrangement of sex and dietary treatments, using the General Linear Model procedures of SAS (2009). Treatment, sex, and interaction between treatment and sex were defined as sources of variation. Significant differences between means were evaluated by Duncan multiple range test (Duncan, 1955) after a significant F-test. Significance was declared at $P<0.05$; $P$-values less than 0.001 are expressed as " $<0.001$ " rather than the actual value. For response of probiotics hormones concentrations, data were expressed as mean standard error of the mean (SEM), which represents the pooled SEM for the model. Moreover, data were analyzed One-Way ANOVA using GraphPad Prism (Version 5) and presented as mean \pm SEM of four independent biological replicates. 


\section{RESULTS}

Growth performance:

The growth performance, as affected by probiotics supplementations to the diets at $150 \mathrm{~g} / \mathrm{kg}$, $300 \mathrm{~g} / \mathrm{kg}$ and $450 \mathrm{mg} / \mathrm{kg}$, are presented in Table (2). Body weight gain was significantly increased by supplementing probiotic levels during 0-2 wk, 4-6 wk and $0-6 \mathrm{wk}$ (at the start, end and the whole experimental period) of the experimental period. On the other hand, feed intake exhibited a noticeable significance $(\mathrm{P}<0.05)$ in interaction between treatments and sex in the period from 4-6 wk only (at the end); whereas for sex and treatments there was absence of any significance difference. Additionally, total feed conversion ratio indicated significant improvement $(\mathrm{P}<0.05)$ for rabbit fed on probiotics levels during period (0-2 and 0-6 weeks), compared to the control.

Table 2. Effects (Mean \pm SEM) of probiotic levels on growth performance of New rabbits

\begin{tabular}{|c|c|c|c|c|c|c|c|c|c|c|}
\hline \multirow[t]{2}{*}{ Items } & \multicolumn{2}{|c|}{ SEX } & \multicolumn{4}{|c|}{ Probiotic levels } & \multirow[t]{2}{*}{$\mathrm{SEM}^{\mathrm{a}}$} & \multicolumn{3}{|c|}{ P-VALUE } \\
\hline & $\mathrm{M}^{\mathrm{b}}$ & $\mathrm{F}^{\mathrm{c}}$ & 0 & 150 & 300 & 450 & & $\mathrm{~S}$ & $\mathrm{~T}$ & SXT \\
\hline \multicolumn{11}{|c|}{ Body weight gain, $g$} \\
\hline $0-2$ week & 405 & 399 & $368^{\mathrm{b}}$ & $385^{\mathrm{b}}$ & $360^{\mathrm{b}}$ & $496^{\mathrm{a}}$ & 19.42 & 0.870 & 0.049 & 0.593 \\
\hline 2-4week & 475 & 415 & 438 & 433 & 440 & 471 & 12.70 & 0.014 & 0.626 & 0.150 \\
\hline 4-6week & 319 & 335 & $368^{\mathrm{a}}$ & $376^{\mathrm{a}}$ & $370^{\mathrm{b}}$ & $381^{\mathrm{ab}}$ & 18.16 & 0.579 & 0.015 & 0.036 \\
\hline 0-6week & 1200 & 1151 & $1192^{\mathrm{ab}}$ & $1173^{\mathrm{b}}$ & $1210^{\mathrm{ab}}$ & $1348^{\mathrm{a}}$ & 32.35 & 0.379 & 0.038 & 0.074 \\
\hline \multicolumn{11}{|c|}{ Feed intake, $\mathrm{g}$} \\
\hline 0-2week & 1186 & 1184 & 1200 & 1200 & 1196 & 1146 & 9.35 & 0.922 & 0.156 & 0.998 \\
\hline 2-4week & 1558 & 1493 & 1541 & 1455 & 1566 & 1542 & 26.08 & 0.204 & 0.436 & 0.192 \\
\hline 4-6week & 1142 & 1112 & 1117 & 1106 & 1141 & 1146 & 22.44 & 0.984 & 0.484 & 0.037 \\
\hline 0-6week & 3888 & 3791 & 3858 & 3762 & 3903 & 3835 & 45.42 & 0.266 & 0.266 & 0.061 \\
\hline \multicolumn{11}{|c|}{ Feed conversion ratio } \\
\hline 0-2week & 3.20 & 3.00 & $3.31^{\mathrm{a}}$ & $3.18^{\mathrm{a}}$ & $3.12^{\mathrm{a}}$ & $2.49^{\mathrm{b}}$ & 0.11 & 0.371 & 0.021 & 0.517 \\
\hline 2-4week & 3.62 & 3.33 & 3.53 & 3.48 & 3.28 & 3.32 & 0.09 & 0.160 & 0.807 & 0.659 \\
\hline 4-6week & 3.34 & 3.47 & 3.04 & 3.21 & 3.63 & 3.74 & 0.13 & 0.584 & 0.177 & 0.228 \\
\hline 0-6week & 3.36 & 3.31 & $3.25^{\mathrm{b}}$ & $3.23^{b}$ & $3.84^{\mathrm{a}}$ & $3.02^{\mathrm{b}}$ & 0.09 & 0.819 & 0.026 & 0.680 \\
\hline
\end{tabular}

\section{Nutrient digestibility:}

Effects of sex and probiotics levels on nutrient digestibility of rabbit are presented in (Table 3). No significant differences were observed on digestibility between males and females and also the interaction between sex and treatments.

Concerning digestibility coefficient of crude protein, nitrogen free extract, dry and organic matter digestibility, they were significantly $(\mathrm{P}<0.01)$ increased with probiotic supplementation from 0 to $450 \mathrm{mg} / \mathrm{kg}$. In addition, noticeable significant $(\mathrm{P}<0.01)$ improvements were observed in digestibility of gross energy at level $150 \mathrm{~g} / \mathrm{kg}$, and crude fiber at level $300 \mathrm{~g} / \mathrm{kg}$, compared to the other treatments and the control, also no significant difference was found in ether extract.

Table 3. Effect (Mean \pm SEM) of probiotic on nutrient digestibility of growing New rabbits

\begin{tabular}{|c|c|c|c|c|c|c|c|c|c|c|}
\hline \multirow[t]{2}{*}{ Items } & \multicolumn{2}{|l|}{ Sex } & \multicolumn{4}{|c|}{ Probiotic levels } & \multirow[t]{2}{*}{$\mathrm{SEM}^{\mathrm{a}}$} & \multicolumn{3}{|c|}{ P-VALUES } \\
\hline & $\mathrm{M}^{\mathrm{b}}$ & $\mathrm{F}^{\mathrm{c}}$ & 0 & 150 & 300 & 450 & & S & $\mathrm{T}$ & SXT \\
\hline Crude protein & 83.94 & 84.01 & $78.37^{\mathrm{C}}$ & $82.66^{b}$ & $85.59^{b}$ & $89.45^{\mathrm{a}}$ & 1.04 & 0.899 & 0.0001 & 0.954 \\
\hline Crude fiber & 53.85 & 48.88 & $38.49^{\mathrm{b}}$ & $56.32^{\mathrm{a}}$ & $56.62^{\mathrm{a}}$ & $54.04^{\mathrm{a}}$ & 2.56 & 0.297 & 0.039 & 0.896 \\
\hline Gross energy & 76.34 & 74.45 & $66.52^{\mathrm{b}}$ & $79.29^{\mathrm{a}}$ & $77.63^{\mathrm{a}}$ & $78.32^{\mathrm{a}}$ & 1.38 & 0.326 & 0.008 & 0.903 \\
\hline Ether extract & 89.27 & 89.49 & 86.29 & 93.29 & 86.30 & 90.99 & 1.25 & 0.929 & 0.169 & 0.375 \\
\hline Dry matter & 65.19 & 66.72 & $50.01^{\mathrm{c}}$ & $64.06^{\mathrm{b}}$ & $66.87^{\mathrm{b}}$ & $82.88^{\mathrm{a}}$ & 2.89 & 0.680 & 0.0001 & 0.821 \\
\hline Organic matter & 63.23 & 64.32 & $47.73^{\mathrm{c}}$ & $62.14^{\mathrm{b}}$ & $64.77^{\mathrm{b}}$ & $80.45^{\mathrm{a}}$ & 2.90 & 0.775 & 0.0002 & 0.884 \\
\hline $\mathrm{N}$-free extract & 78.12 & 76.96 & $70.23^{b}$ & $79.31^{\mathrm{a}}$ & $78.48^{\mathrm{a}}$ & $82.15^{\mathrm{a}}$ & 1.29 & 0.594 & 0.0007 & 0.203 \\
\hline
\end{tabular}

\section{Carcass criteria:}

Results indicated that there were no significant differences in carcass characteristics including carcass weight, hot carcass, liver, kidney, spleen, lungs, heart and head among probiotic treatments, sex and their interaction (Table 4). However, abdominal fat was significantly different in sex, where the fat ratio was greater in females than males. The tests, gut and caecum weight exhibited a high significance $(\mathrm{P}<0.001)$ among treatments compared to the control group. 
Table 4. Effect (Mean \pm SEM) of probiotic levels on carcass criteria of growing New rabbits

\begin{tabular}{|c|c|c|c|c|c|c|c|c|c|c|}
\hline \multirow[t]{2}{*}{ Items } & \multicolumn{2}{|l|}{ Sex } & \multicolumn{4}{|c|}{ Probiotic levels } & \multirow[t]{2}{*}{ SEM } & \multicolumn{3}{|c|}{ P-VALUES } \\
\hline & $\mathrm{M}$ & $\mathrm{F}$ & 0 & 150 & 300 & 450 & & $\mathrm{~S}$ & $\mathrm{~T}$ & SXT \\
\hline Live $\mathrm{wt}^{\mathrm{d}}$ & $2202^{\mathrm{a}}$ & $2089^{b}$ & 2157 & 2192 & 2129 & 2104 & 24.19 & 0.018 & 0.533 & 0.333 \\
\hline Carcass wt & 1168 & 1124 & 1137 & 1198 & 1135 & 1116 & 18.82 & 0.233 & 0.402 & 0.164 \\
\hline Hotcacarcasswt & 1284 & 1238 & 1242 & 1319 & 1258 & 1229 & 19.11 & 0.198 & 0.286 & 0.127 \\
\hline Carcass \% & 58.37 & 59.31 & 58.23 & 60.11 & 59.51 & 58.26 & 0.704 & 0.531 & 0.674 & 0.434 \\
\hline Liver \% & 4.96 & 4.95 & 4.61 & 5.02 & 5.35 & 4.83 & 0.163 & 0.974 & 0.541 & 0.899 \\
\hline Heart $\%$ & 0.492 & 0.487 & 0.351 & 0.537 & 0.497 & 0.575 & 0.035 & 0.939 & 0.161 & 0.589 \\
\hline Kidney \% & 1.421 & 1.443 & 1.403 & 1.364 & 1.434 & 1.527 & 0.065 & 0.885 & 0.881 & 0.758 \\
\hline Spleen \% & 0.152 & 0.170 & 0.155 & 0.150 & 0.180 & 0.159 & 0.007 & 0.226 & 0.501 & 0.366 \\
\hline Lunges \% & 1.060 & 1.230 & 1.059 & 1.011 & 1.492 & 1.019 & 0.082 & 0.288 & 0.123 & 0.585 \\
\hline Fat abdomen $\%$ & $0.561^{\mathrm{b}}$ & $0.972^{\mathrm{a}}$ & 0.703 & 0.919 & 0.715 & 0.730 & 0.0997 & 0.046 & 0.834 & 0.324 \\
\hline Head \% & 5.728 & 5.045 & 5.185 & 4.823 & 4.803 & 6.733 & 0.380 & 0.377 & 0.257 & 0.528 \\
\hline Cecum $\%$ & 0.347 & 0.383 & $0.278^{\mathrm{b}}$ & $0.489^{\mathrm{a}}$ & $0.359^{b}$ & $0.334^{\mathrm{b}}$ & 0.020 & 0.181 & 0.0003 & 0.230 \\
\hline GUT \% & 16.40 & 17.27 & $17.94^{\mathrm{a}}$ & $14.83^{\mathrm{b}}$ & $18.700^{\mathrm{a}}$ & $15.86^{\mathrm{ab}}$ & 0.551 & 0.368 & 0.036 & 0.313 \\
\hline $\operatorname{CECUM}(\mathrm{cm})$ & 10.50 & 10.33 & 10.16 & 10.50 & 10.66 & 10.33 & 0.020 & 0.736 & 0.897 & 0.166 \\
\hline GUT (cm) & 3.241 & 3.225 & 3.383 & 3.233 & 3.233 & 3.083 & 0.551 & 0.938 & 0.804 & 0.627 \\
\hline
\end{tabular}

${ }^{\mathrm{a}-\mathrm{b}}$ Means bearing different superscripts within a row differ significantly $(P<0.05)$.

$\mathrm{SEM}^{\mathrm{a}}$, standard error of means $\quad \mathrm{M}^{\mathrm{b}}$, Male; $\mathrm{F}^{\mathrm{c}}$, Female

\section{Blood parameters:}

Supplementation of dietary probiotic showed a significant decrease in blood glucose levels, followed by an increase, in the probiotic level of $450 \mathrm{mg} / \mathrm{kg}$. This increase may be attributed to the higher digestibility of crude protein and decrease in cholesterol $(\mathrm{P}<0.001)$ at probiotic levels of 150,300 and $450 \mathrm{mg} / \mathrm{kg}$, respectively. With respect to the total protein and $\mathrm{T} 3$, significant increases $(\mathrm{p}<0.05$ and $\mathrm{p}<0.001$ respectively) were observed for all treatments (Table 5), whereas sex and interactions between sex and treatments did not show any significance. On the other hand, T4 did not show any significance at any treatment level, sex and their interaction.

Finally, sex hormones, as represented by levels of testosterone (Fig. 1), and estrogen (Fig. 2) exhibited a high significance $(\mathrm{P}<0.05)$ at the level of 150 and $450 \mathrm{mg} / \mathrm{kg}$ than control and the first treatment level, on the other hand progesterone (Fig. 3) showed high significance $(\mathrm{P}<0.05)$ at level 300 $\mathrm{mg} / \mathrm{kg}$ compared to control and other treatment levels.

Table 5. Effect (Mean \pm SEM) of probiotic on serum biochemical profile of growing New rabbits

\begin{tabular}{|c|c|c|c|c|c|c|c|c|c|c|}
\hline \multirow[t]{2}{*}{ Items } & \multicolumn{2}{|c|}{ SEX } & \multicolumn{4}{|c|}{ Probiotic levels } & \multirow[t]{2}{*}{$\mathrm{SEM}^{\mathrm{a}}$} & \multicolumn{3}{|c|}{ P-VALUE } \\
\hline & $\mathrm{M}^{\mathrm{b}}$ & $\mathrm{F}^{\mathrm{c}}$ & 0 & 150 & 300 & 450 & & $\mathrm{~S}$ & $\mathrm{~T}$ & SXT \\
\hline Glucose(mg/dl) & 78.91 & 82.08 & $88.66^{b}$ & $57.50^{c}$ & $80.16^{\mathrm{b}}$ & $95.66^{\mathrm{a}}$ & 2.29 & 0.415 & 0.0001 & 0.003 \\
\hline Cholesterol(mg/dl) & 72.66 & 74.08 & $93.66^{\mathrm{a}}$ & $73.83^{b}$ & $42.83^{\mathrm{c}}$ & $83.16^{\mathrm{ab}}$ & 1.82 & 0.803 & 0.0001 & 0.047 \\
\hline Total protean $(\mathrm{g} / \mathrm{l})$ & 6.67 & 6.57 & $6.66^{\mathrm{a}}$ & $6.75^{\mathrm{a}}$ & $6.16^{\mathrm{b}}$ & $6.91^{\mathrm{a}}$ & 0.090 & 0.490 & 0.010 & 0.191 \\
\hline T3(ng/dl) & 66.75 & 56.66 & $57.33^{b}$ & $81.33^{\mathrm{a}}$ & $74.33^{\mathrm{b}}$ & $58.16^{\mathrm{b}}$ & 3.675 & 0.082 & 0.006 & 0.243 \\
\hline T4(ng/dl) & 3.53 & 3.49 & 3.48 & 3.72 & 3.54 & 3.28 & 0.139 & 0.897 & 0.805 & 0.896 \\
\hline
\end{tabular}

${ }^{\mathrm{a}-\mathrm{b}}$ Means bearing different superscripts within a row differ significantly $(P<0.05)$.

$\mathrm{SEM}^{\mathrm{a}}$, standard error of means $\quad \mathrm{M}^{\mathrm{b}}$, Male; $\mathrm{F}^{\mathrm{c}}$, Female

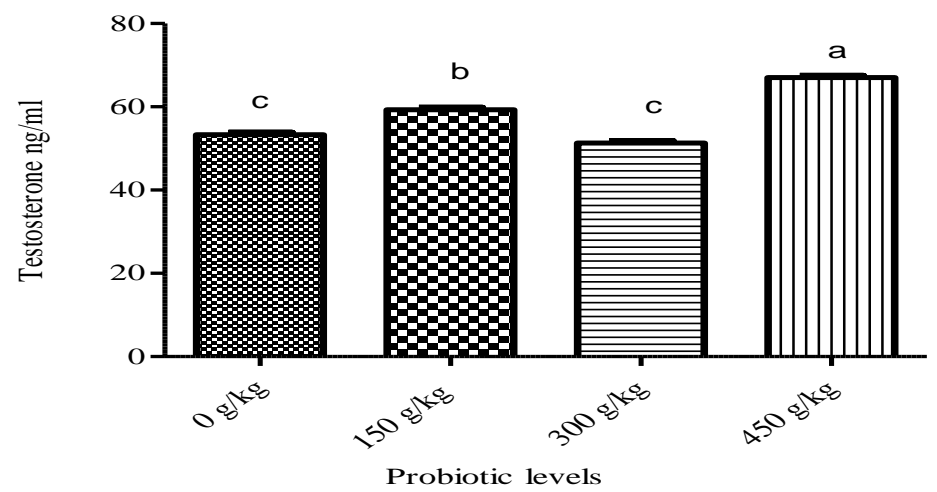

Figure 1. Serum levels $(\mathrm{ng} / \mathrm{ml})$ of total testosterone secretion in response to Probiotic supplementation of 150,300 and $450 \mathrm{~g} / \mathrm{kg}$, or a control $(0 \mathrm{~g} / \mathrm{kg})$ in male New rabbits. Letters on the bars a, b, c denote the significant difference among the different treatments $(\mathrm{P}<0.05)$ 


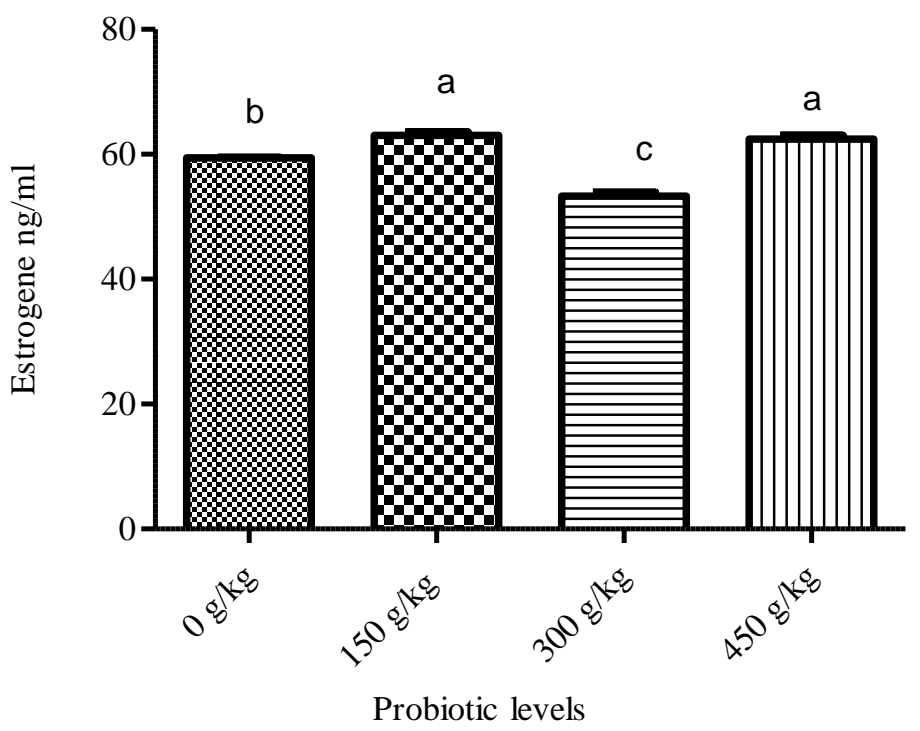

Figure 2. Serum levels of estrogen secretion in response to Probiotic supplementation of 150,300 and 450 $\mathrm{g} / \mathrm{kg}$, or a control $(0 \mathrm{~g} / \mathrm{kg})$ in female New rabbits. Letters on the bars a, b, c denote the significant difference among the different treatments $(\mathbf{P}<0.05)$

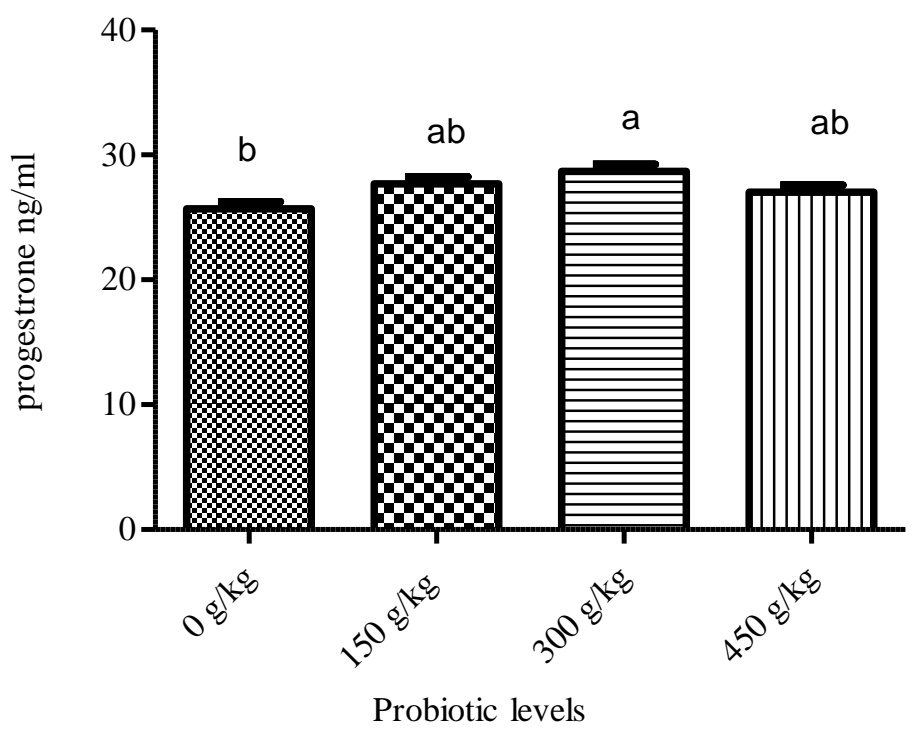

Figure 3. Serum levels of progesterone secretion in response to Probiotic supplementation of 150,300 and $450 \mathrm{~g} / \mathrm{kg}$, or a control $(0 \mathrm{~g} / \mathrm{kg})$ in female New rabbits. Letters the bars a, b, c denote the significant difference among the different treatments $(P<0.05)$

\section{Meat quality:}

The effects of probiotic supplementation on meat quality characteristics of rabbits at the end of experimental period are shown in Table (6). Probiotic supplemented groups resulted in a significant decrease $(\mathrm{P}<0.05)$ in water holding capacity at level of 150 and $300 \mathrm{mg} / \mathrm{kg}$, followed by an increase in the last level $450 \mathrm{mg} / \mathrm{kg}$, compared to the control. Also, significance was observed in the interaction between probiotic levels and sex; meanwhile, there was no significance for sex. Concerning the water holding capacity (WHC), and $\mathrm{pH}$ values, no observable significance was found. On the other hand, females exhibited a significant increase $(\mathrm{P}<0.001)$ in the cooking loss than males. Again, observed significance for sex in cooking loss was not significant in the treatments and interaction. Finally, there were no significant differences in $\mathrm{PH}$ value at probiotic treatments, sex and their interaction. 
Table 6. Effect (Mean \pm SEM) of probiotic on meat quality of growing rabbits

\begin{tabular}{|c|c|c|c|c|c|c|c|c|c|c|}
\hline \multirow[t]{2}{*}{ Items } & \multicolumn{2}{|l|}{ Sex } & \multicolumn{4}{|c|}{ Probiotic levels } & \multirow[t]{2}{*}{ SEM } & \multicolumn{3}{|c|}{ P-VALUE } \\
\hline & $\mathrm{M}$ & $\mathrm{F}$ & 0 & 150 & 300 & 450 & & $\mathrm{~S}$ & $\mathrm{~T}$ & SXT \\
\hline Water capcity & 32.28 & 30.40 & $34.30^{\mathrm{a}}$ & $24.86^{b}$ & $31.2^{\mathrm{a}}$ & $35.00^{\mathrm{a}}$ & 1.39 & 0.379 & 0.013 & 0.046 \\
\hline $\mathrm{PH}$ & 6.25 & 6.17 & 6.29 & 6.46 & 6.12 & 5.98 & 0.08 & 0.578 & 0.174 & 0.228 \\
\hline Cooking loose & $18.08^{\mathrm{b}}$ & $22.22^{\mathrm{a}}$ & 21.39 & 18.41 & 21.2 & 19.51 & 0.78 & 0.004 & 0.291 & 0.193 \\
\hline
\end{tabular}

${ }^{\mathrm{a}-\mathrm{b}}$ Means bearing different superscripts within a row differ significantly $(P<0.05)$.

SEM, standard error of means $\quad M^{\mathrm{b}}$, Male; $\mathrm{F}^{\mathrm{c}}$, Female

\section{DISCUSSION}

\section{Productive performance:}

Effects of probiotics supplementation on growth performance indices of growing rabbits during the experiment are shown in Table (2). The results showed that the groups supplemented with 300 and $450 \mathrm{mg} / \mathrm{kg}$ of probiotic exhibited significantly $(p<0.05)$ higher body weight gain than the control. The increased body weight gain could be attributed to the improved protein digestibility and increased efficiency of feed utilization (Martin et al., 1989; Numan, 2001; and Ezema, 2007). Shrivastava et al. (2012) reported that the increase in growth performance in rabbits fed a ration supplemented with probiotic may be due to increased digestion and absorption through the intestine. In addition, Chandra et al. (2014) attributed the improvement in growth performance to good digestibility and absorption in the ilea. Nevertheless, Attia et al. (2012) concluded that the positive effect of probiotics on growth performance resulted from change in gut microbiota. The present results showed feed intake were slightly higher in probiotic supplemented groups, which is in agreement with observation made by earlier workers such as (Onifade et al., 1999; Adejumo et al., 2005; Shehu et al., 2014; Amber et al., 2014; and Iwu et al., 2015).

In view of the obtained results on FCR, it may be concluded that they were in close harmony with the results of Adeniji and Adewole (2015) who reported a significant effect on FCR upon replacing brewers dried grains for groundnut cake with or without probiotics supplementation.; Amber et al. (2014) in supplementing rabbits basal diet with a mixture of probiotics (i. e. Bio-MOS Reg; mannan oligosaccharide at $1 \mathrm{~g} / \mathrm{kg}$ diet) and a probiotic ( i.e. Bio-Plus Reg.2B, Bacillus subtilisand Bacillus licheniformis at $0.4 \mathrm{~g} / \mathrm{kg}$ diet) had significant effects on feed efficiency among the group. Adeniji et al. (2013 and 2014) observed significant influence on the feed to gain ratio upon supplementation of rabbits with probiotic. El-Kholy et al. (2012) also reported significantly higher FCR in case of diet supplemented with E. Faecalis as compared to control group of NZW rabbits. Additionally, Karima et al. (2011) also confirmed an improved FCR (about $13.0 \%$ and $13.1 \%$ ) with dietary supplementation by Lactobacillus strains. Chrastinova et al. (2010) reported better FCR of New Zealand white rabbits in comparison with the control group upon supplementation with Phyto-additives and probiotics. On the other hand, Ezema et al. (2015 and 2012) reported that there was no significant difference in FCR among rabbits fed at different probiotic diet levels. However, Thanh and Jamikorn (2012) noted that the FCR was reduced significantly in weaning New Zealand White rabbits diets supplemented with L. acidophilus and B. subtilisas compared to the control diet.

\section{Digestibility:}

The nutrient digestibility of the rabbits was significantly $(\mathrm{P}<0.05)$ increased by the dietary treatments. The effect of supplementing probiotics on digestibility of rabbits has not been fully addressed by researchers. Yamani et al. (1992) stated that using lacto-sacc (a complex product containing not only a mixture of the micro-organisms Lactobacillus acidophilus, Streptococcus faecium and yeasts, but also the enzyme protease, cellulases, and amylase) improved crude fibre digestibility. Also, Amber et al. (2004) worked with Lact-A-Bac (Lactobacillus acidophilus) and reported an improvement in the digestibility of energy and most analytical fractions (dry matter, crude protein, ether extract) including crude fibre which corroborates the results obtained in this study.

In general, probiotic supplementation has been reported to show a positive influence on nutrient utilization due to its ability to fortify beneficial members of the intestinal microbiota, thereby improving efficiency of nutrient digestion and absorption processes of the host (Mountzouris et al., 2010). In probiotics-supplemented groups, the higher digestibility of crude protein and fiber components (NDF, hemicelluloses) could be the result of maintaining a relatively better health and environmental gut microbiota that supported improvement in nitrogen utilization and growth with efficient FCR (Combes et al., 2012).

\section{Carcass characteristics:}

Results indicated that rabbits were insignificantly $(\mathrm{P}<0.05)$ influenced by probiotics dietary supplements except the testicles, caecum and gut weights which were statistically $(\mathrm{P}<0.001)$ impacted. Meanwhile no significant differences were noted in dressing percentage at 150 and $300 \mathrm{mg} / \mathrm{kg}$ probiotic levels. These results are in agreement with those reported by Ewuola et al. (2011) who observed no significant differences in carcass characters among 
all treatment groups upon supplementation of growing New Zealand white rabbits with enzymes and probiotic mixture (Veta-zyme), prebiotics and symbiotics. An increased caecum weight in weaning rabbits upon dietary inclusion of a probiotic was reported (Rotolo et al., 2014).

\section{Serum biochemical parameters:}

Biochemical blood parameters are usually good indicators for physiological, pathological, and nutritional status of an animal and have the potential of being used to elucidate the impact of nutritional factors and additives supplied in diet (Ashour et al., 2014). In the current study, blood constituents indicate significant decrease in glucose at 150 and $300 \mathrm{mg} / \mathrm{kg}$ probiotic levels followed by an increase at $450 \mathrm{mg} / \mathrm{kg}$, compared to the control. Concerning cholesterol values, all levels at 150, 300 and 450 $\mathrm{mg} / \mathrm{kg}$ showed a significant decrease $(\mathrm{p}<0.001)$ in comparison with the control group. Our results also were in line, and in physiological normal range, with those obtained by Abd-El-hady et al. (2015) who reported that rabbits fed with prebiotic, probiotic had significantly reduced glucose $(\mathrm{P}<0.05)$, cholesterol and triglycerides $(\mathrm{P}<0.001)$, compared with control group. Also, Simonova et al. (2013) noted that dietary supplementation with Enterococcus faecium CCM7420 (EF) and E. senticosus extract (ES) or their combination $(\mathrm{EF}+\mathrm{ES})$ had a significant decrease $(\mathrm{P}<0.05)$ in glucose among groups. Furthermore, rabbit groups fed probiotic supplemented diet showed a significant $(\mathrm{P}<0.05)$ decrease in cholesterol and triglyceride concentrations when compared to the control. Similar results were reported by other workers (Arun et al., 2006; Ashayerizadeh et al., 2011; Amer and Khan, 2012; and Mokhtar, 2013) who reported significant reduction in serum total cholesterol and triglycerides by dietary supplementation of probiotic. The significant reduction in serum cholesterol of rabbits fed probiotic supplemented diet could be attributed to reduced absorption or synthesis of cholesterol in the gastro-intestinal tract by probiotic supplementation (Mohan et al., 1996). Also, it was speculated that Lactobacillus acidophillus reduces the cholesterol in the blood by deconjugating bile salts in the intestine, thereby preventing them from acting as precursors in cholesterol synthesis. (Abdulrahim et al., 1996). Deconjugated bile acids are less soluble at low $\mathrm{pH}$ and less absorbed in the intestine and is more likely to be excreted in faeces. (Klaver and Van der Meer, 1993). This could be the case in the present study, thus forcing de novo bile synthesis in the liver from body cholesterol pool, causing a net reduction in total blood cholesterol level as one of the probiotic microbes utilized in the study (Lactobacillus acidophillus) is acidophilic which lowers the $\mathrm{pH}$ of the surrounding environment. Another explanation of the mechanism by which a probiotic can lower the serum cholesterol has been declared by Fukushima and Nakano (1995). The authors demonstrated that probiotic microorganisms inhibit hydroxymethylglutaryl-coenzyme A; an enzyme involved in the cholesterol synthesis pathway thereby decrease cholesterol synthesis. Corcoran et al. (2005) reported that fat digestion rate is linked to the rate of gall bladder acids in digestion latex and subsequently the lipid concentration. Supplementation of probiotics in diet cause a decrease in gall bladder acids in digestion latex and this resulted in a reduction of fat digestion and therefore decreasing lipid level of blood (Corcoran et al., 2005).

In the present study, serum total protein (T.P), significantly increased $(\mathrm{P}<0.05)$ at 150 and 450 $\mathrm{mg} / \mathrm{kg}$ levels; whereas it showed a decrease at 300 $\mathrm{mg} / \mathrm{kg}$ level of supplementation probiotics in diets. This might be due to the higher digestibility of crude protein in these diets (Amber, 2000). Meanwhile, T3 concentrations was significantly $(\mathrm{P}<0.001)$ increased at 150,300 and with a slight increase at $450 \mathrm{mg} / \mathrm{kg}$ in probiotics supplemented treatments, compared to the control group. In the current study, sex hormones, represented by testosterone, estrogens and progesterone exhibited a high significance $(\mathrm{P}<0.05)$ compared to control. Our results were in agreement with those reported in the literature that probiotics caused enhancement of testosterone level, which may be interpreted, along with the hypocholesterolemic action of probiotics, by mobilization of blood cholesterol to testosterone synthesis (Huey-Shi et al.,2009; Daniela et al., 2009; Lay-Gaik and Min-Tze, 2010; Ghoneim and Moselhy, 2012;). In our results the concentration of blood serum testosterone tended to be lower when the probiotic level reached dose of $300 \mathrm{mg} / \mathrm{kg}$ compared to 150 and $400 \mathrm{mg} / \mathrm{kg}$. This reduction in testosterone concentration may be due to the hypocholesterolemic action of probiotics at this level. Also, Martarelli et al. (2011) who reported that supplementation of probiotic had a beneficial effect of reducing the severity of the changes within the somniferous tubules and improve testicular profile, as observed in histological study.

\section{CONCLUSIONS}

Obtained results support the addition of probiotics in the rabbit diets at level of $450 \mathrm{mg} / \mathrm{kg}$ to enhance of productive performance, nutrient digestibility, blood biochemistry and sexual hormone without any adverse effect on carcass criteria. Further detailed studies are required to establish the reproductive efficiency of adults rabbits under Upper Egyptian hot summer condition.

\section{REFERENCES}

Abdelhady, D.H., and M.A. El-Abasy, 2015. Effect of prebiotic and probiotic on growth, immunohematological responses and biochemical 
parameters of infected rabbits with Pasteurellamultocida. Benha Veterinary Medicine Journal, 28:40-51.

Abdel-Wareth, A.A.A., S. Hammad and H. Ahmed, 2014. Effects of Khaya senegalensis leaves on performance, carcass traits, hematological and biochemical parameters in rabbits. EXCLI. J, 13:502-512.

Abdel-Wareth, A.A.A., S. Kehraus, F. Hippenstiel, and K-H. Südekum, 2012. Effects of thyme and oregano on growth performance of broilers from 4 to 42 days of age and on microbial counts in crop, small intestine and caecum of 42-day-old broilers. Anim Feed Sci Technol ,178:198-202.

Abdel-Wareth, A.A.A., S. Kehraus, H.H.A. Abdalla, Z.S.H. Ismail and K-H. Südekum, 2015. Effects of temporary intensive feed restriction on performance, nutrient digestibility and carcass criteria of growing male Californian rabbits. Archives of Animal Nutrition, 69: 6978 .

Abdulrahim, S.M., M.S.Y. Haddadin, E.A.R. Hashlamoun and R.K. Robinson, 1996. The influence of Lactobacillus acidophilus and bacitracin on layer performance of chickens and cholesterol content of plasma and egg yolk. British Poultry Science, 341- 346.

Adejumo, D.O., A.A. Onifade, T.O. Olutunde and G.M. Babatune, 2005. The effect of concentration, age and duration of feeding supplemental yeast Adene, OF, 2004. Poultry Health and Production Principles and Practices. Striling-Horden Publishers (Nig.) Ltd. Ibadan, Nigeria. P, 45

Adeniji, A.A. and O.A., Adewole, 2015. Effects of Feeding Graded Levels of Brewers Dried Grains with or without Probiotics Supplementation in Replacing Groundnut Cake in the Diet of Weaner Rabbits. Journal of Natural Sciences Research, 5: 155-164.

Adeniji, A.A., H. Duwa and M. Umar, 2014. Global Journal of Biology, Agriculture \& Health Sciences, 3:48-54.

Adeniji, A.A. and N. Zubairu, 2013. Nutritional value of palm kernel cake supplemented with or without probiotics to replace groundnut cake in the diets of weaner rabbits. Journal of Animal Science Advances, 3: 517-523.

Alkhalf, A., M. Alhaj and I. Al-homidan, 2010. Influence of probiotic supplementation on blood parameters and growth performance in broiler chickens. Saudi Journal of Biological Sciences, 17: 219-225.

Amber, K., F.M.A. El-Nabi, W.A. Morsy and S.H.A. Morsy, 2014. Effect of dietary supplementation of probiotic and prebiotic on preventing post weaning digestive disorders and productive performance of growing rabbits. Egyptian Poultry Science Journal, 34:19-38.
Amber, K.h., 2000. Effect of replacing mung beans (Phaseolusaureus) for soybean meal in diets for growingrabbits. Proc. of 7th World Rabbit Congress, Valencia, Vol. A, pp, 69-75.

Amber, K.H., H.M. Yakout and H.S. Rawya, 2004. Effect of feeding diets containing yucca extract or probiotic on growth, digestibility, nitrogenbalance and caecal microbial activity of growing New Zealand whiterabbits. Proceedings of the 8th World Rabbit Congress, Puebla(México). P,737-741.

Amer, M.Y. and S.H. Khan, 2012. A comparison between the effects of aprobiotic and an antibiotic on the performance of Desichickens. Veterinary World, 5:160-165.

AOAC., 2006. Official methods of analysis 17th edition', Assoc. Off. Anal. Chem, Arlington, Virginia, USA.

Archetti, L., C. Tittarelli, M. Cerioli, R. Brivio, G. Grilli and A. Lavazza, 2008. Serum chemistry and hematology values in commercial rabbits: Preliminary data from industrial farms in northern Italy. In Proceedings of the 9th World Rabbit Congress Verona, Italy, pp, 1147-1152.

Arun, K.P., R. Rao, V. Savaram, V.L.N. Mantena, S. Raju and R. Sharma, 2006. Dietary supplementation of Lactobacillus Sporogenes on performance and serum biochemico-lipid profile of broiler chickens. Journal of Poultry Science, 43: 235-240.

Ashayerizadeh, A., N. Dabiri. K.H. Mirzadeh M.R. Ghorbani, 2011. Effect of dietary supplementation of probiotic and prebiotic on growth indices and serum biochemical parameters of broiler chickens. Journal of Cell and Animal Biology, 5:152-156.

Ashour E.A., M. Alagawany, F.M. Reda and M.E. Abd ElHack, 2014. Effect of supplementation of Yucca Schidigera extract to growing rabbit diets on growth performance, carcass characteristics, serum biochemistry and liver oxidative status. Asian J. Anim. Vet. Adv. 9, 732-742

Attia K.A., Y. Sohair Saleh, S. Abd El-hamid A. Safaa, ZakiAmal and A. AEl-Sawy Mohamed 2012. Effect ofExogenous Multi-enzyme Feed Additive probiotics on the Activities of Certain Digestive of:Enzymes and Intestinal Morphology in Growing 23-29.Rabbits. Journal of Agriculture Science, 4:35-44.

Awaad, M., A. Atta, M.A. Elmenawey, B. Shalaby, G. Abdelaleem, K. Madian, K. Ahmed, D. Marzin, G. Benzoni and D. Iskander, 2011. Effect of acidifiers on gastrointestinal tract integrity, zootechnical performance, and colonization of clostridium perfringens and aerobic bacteria in broiler chickens. J. Anim. Sci, 7:618-628.

Burtis, C.A., and E.R. Ashwood, 1994. Tietz textbook of clinical chemistry, 2nd edn. W B Saunders Company, Philadelphia. 
Chandra, S., M. Mahender, M.G. Prakash, T. Raghunandan and K.K. Reddy, 2014. Productive performance of broiler rabbits fed diets supplemented with probiotic and rnzymes under two systems of housing. . Indian J. Anim. Res, $48: 355-361$

Chantalakhana, C., 1990. Small Farm animal production and sustainable agriculture; In: Proceedings 5th AAAP Animal Science Congress held in Taipei, Taiwan vol, 11: 36-64. The Asian-Australian Association of Animal Production Societies Taipei, Taiwan

Chrastinova L, M. Chrenkova, A. Laukova M. Polacikova, M. Simonova, R. Szaboova V. Strompfova, L. Ondruska, I. Chlebec, V. Parkanyi J. Rafay and Z. Vasilkova, 2010. Influence of selected phytoadditives and probiotics on zootechnical performance, caecal parameters and meat quality of rabbits. Archiva Zootechnica, 13: 30-35.

Combes, S., L. Fortun-Lamothe, L. Cauquil and T. Gidenne, 2012. Controlling the rabbit digestive ecosystem to improve digestive health and efficacy. Proceedings of the 10th World Rabbit Congress; 2012 September 3-6, Sharm ElSheikh (Egypt). P,. 475-494.

Corcoran B.M., C. Stanton, G.F. Fitzgerald and R.P. Ross, 2005. Survival of probiotic lactobacilli in acidic environments is enhanced in the presence of metabolizable sugars. Applied and Environmental Microbiology, 71: 306-030

Cyril, H.W., C. Castellini and A. Dal Bosco, 1996. Comparison of three cooking methods of rabbit meat. Ital J Food Sci, 8(4):337-340.

Dalloul, R.A., H.S. Lillehoj, T.A. Shellem and J.A. Doerr, 2003. Enhanced mucosal immunity against Eimeriaacervulina in broilers fed a Lactobacillus-based probiotic. Poul. Sci. 82:6266.

Daniela, C.C., B. Raquel, Q.B. Laura, C.V. Regina and A.R. Elizeu, 2009. Effects of probiotic bacteria, isoflavones and simvastatin on lipid profile and atherosclerosis in cholesterol-fed rabbits: a randomized double-blind study. Lipids in Health and Disease, 8:1-8.

Duncan, D. B., 1955. Multiple range and multiple F-Test, Biometrics, 11:1-42.

El-Kholy, K.H., S.Z. El-Damrawy and T.S.T. Seleem, 2012. ${ }^{5}$ th Science Congress of Egypt. Society for Animal Management,142-157.

Ewuola, E. O., C.U. Amadi and T.K. Imam, 2011. Performance evaluation and nutrient digestibility of rabbits fed dietary prebiotics, probiotics and symbiotics. International Journal of Applied Agricultural and Apicultural Research, 7:107117.

Ezema, C., 2007. The performance of Broilers Fed Palm Kernel Cake-Based Diet Supplemented with Bioactive Yeast, MSc. Dissertation. Department of Animal Health and Production,
Faculty of Veterinary Medicine, Medicine, University of Nigeria, Nsukka.

Ezema, C. and D.C. Eze, 2012. Determination of the effect of probiotic (Saccharomyces cerevisiae) on growth performance and haematological parameters of rabbits. Comparative Clinical Pathology, 21:73-76.

Ezema, C. and D.C. Eze, 2015. Growth performance and cost benefit of weaner rabbits fed diet supplemented with probiotic in the tropics. Pakistan Journal of Nutrition ,14: 47-49.

Falcão -e-Cunha, L., L. Castro-Solla, L. Maertens, M. Marounek, V. Pinheiro, J. Freire and J.L. Mour, 2007. Alternatives toantibiotic growth promoters inrabbit feeding: a review. World Rabbit Science, 15:127-140.

Felig P., J.D. Baxter A.E., Broadus, and L.A. Frohman, 1987. Endocrinology and metabolism, 2nd Ed. New York, McGraw-Hill book Co, pp 408-416

Fukushima, M. and M. Nakano, 1995. The effect of probiotic on faecal and liver lipid classes in rats. British Journal of Nutrition, 73:701 - 710.

Ghadban, G.S., 2002. Probiotics in broiler production-A review. Arch. Für Geflügelkunde, 66: 49-58.

Ghoneim, M.A. and S.S. Moselhy, 2012. Impact of probiotic supplemented diet on the expression level of leukocytic lactate dehydrogenase of rabbits. Toxicology and Industrial Health. Epub ahead of print 3 August 2012.

Huey-Shi - L., K. Chiu-Yin, E Joo-Ann, F. WaiYee, L. Min-Tze, 2009. The improvement of hypertension by probiotics: Effects on cholesterol, diabetes,renin, and phytoestrogens. International Journal of Molecular Sciences, 10:3755-3775.

Ismail, A.A., P. Astley, W.A. Burr, M. Cawood, F. Short, K. Wakelin and M.J. Wheeler, 1986. The role of testosterone measurement in the investigation of androgen disorders. Ann. Clin. Biochem, 23:113-134.

Iwu, C. J., IM. Iwu and P.C. Aguihe, 2015. International Journal of Applied Research and Technology, 4: $116-120$.

Karima, M., M.I.Y., El- Katcha, E.Y. Ismail and M.A. Soltan, 2011. Effect of dietary probiotics supplementation on growth performance, immune response, some blood parameters and carcass quality of growing rabbits.Alexandria Journal of Veterinary Science,34: 153-169.

Klaver, F.A.M. and R. van der Meer, 1993. The assumed assimilation of cholesterol by Lactobacilli and Bifidobacteriumbifidum is due to their bile salt deconjugating activity. Applied Environmental Microbiology, 59:120-1124.

Korkeala H., O. Mäki-Petais, T. Alanko and O. Sorvettula 1984.Determination of $\mathrm{pH}$ in meat. Meat Sci.,18:121-125. 
Lay-Gaik, O. and L. Min-Tze, 2010.Cholesterollowering effects of probiotics and prebiotics: a review of in vivo and in vitro findings.

International Journal of Molecular Sciences., 11: 2499-2522.

Lebas, F., 2004. Reflections on rabbit nutrition with a special emphasis on feed ingredients utilization. Proceedings of 8th World Rabbit Congress; 2004 Sep 7-10; Puebla; [cited Aug 11]. Available from: http://cuniculture.info/Docs/Documentation/Pub li-Lebas/2000-2009/2004-Lebas-WRCRevuesources-matiere-premieres-Puebla.pdf.

Lebas, F., P. Coudert, R. Rouvier and H. Rochambeau, 1984. The rabbit: husbandry, health and production. FAO Animal Production and Health Series, no. 21. Rome: FAO.

Martarelli, D., M.C. Verdenelli, S. Scuri, M. Cocchioni, S. Silvi, C. Cecchini and P. Pompei, 2011. Effect of a probiotic intake on oxidant and antioxidant parameters in plasma of athletes during intense exercise training. Current Microbiology ,62: 1689-1696.

Martin, S.A., B.J. Nisbel and R.F. Dean, 1989. Influence of a commercial yeast supplement on the in-vitro ruminal fermentation. Nutr. Reprod. Int, 40:395403.

Melillo, A., 2007. Rabbit clinical pathology. Journal of Exotic Pet Medicine, 16: 135-145.

Mohan, B., R. Kadirvel, M. Natarajan, M. Bhaskaran, 1996. Effect of probiotic supplementation on growth, nitrogen utilization and serum cholesterol in broilers. Br. Poult. Sci., 37:395-401.

Mokhtar, F., 2013. Effects of lactobacillus culture as probiotic on blood performance, plasma enzyme activities and mortality in broiler chickens. Research Journal of Animal Science, 7: 77-81

Mountzouris, K.C., P. Tsitrsikos, I. Palamidi, A. Arvaniti, M. Mohnl, G. Schatzmayr and K. Fegeros, 2010 .Effect of probiotic inclusion levels inbroiler nutrition on growthperformance, nutrient digestibility, plasmaimmunoglobulins and cecalmicroflora composition. Poult. Sci, 89:58 - 67.

Nakamura, M. and K. Katoh, 1985. Influence of thawing method on several properties of rabbit meat. Bulletin of Ishikawa Prefecture College of Agriculture, 11:45-49.

Numan, 2001. Heterologous expression of genes in the yeast Saccharomyces cerevisiae. Turk. J. Agric, 25: 45-49.

Onifade, A.A., R.1. Obiyan, E. Onipede, D.O. Adejumo, O.A. Abu and G.M. Babatunde, 1999. Assessment of the effect of supplementing rabbits diet with a culture of Saccharomyces cerevisiaeusing growth performance, blood composition and clinical enzymes activities. Anim. Feed Sci. Technol., 77: 25-32.
Owen, V., 1981. Rabbit meat for developing countries. World Anim Rev, 9:2-10

Ozcan, N., 2001. Heterologous expression of genes in the yeast saccharomyces cerecisiae. Turk $\mathbf{J}$ Agric For, 25-45.

Rotolo. L., F. Gai., P.G. Peiretti, Ortoffi, I., Zoccarato and L. Gasco 2014. Live yeast (Saccharomyces cerevisiae var. boulardii) supplementation in fattening rabbit diet. Effect on productive performance and meat quality. LivestockSci, 162:178-184.

Rautray, A.K., R.C. Patra, K.K. Sardar, and G. Sahoo, 2011. Potential of probiotics in livestock production. EAMR, 1:20-28.

Santin, E.A., M., Maoirka, M. Macari, J.C. Grecco, T.M. Sanchez, Okada and A.M. Myasaka, 2001. Performance and intestinal mucosa development of broiler chickens fed diets containing Saccharomyces cerevisiaecell wall. J. Appl. Poult. Res, 10:236-244.

SAS [SAS Institute], 2009. SAS/STAT ${ }^{\circledR} 9.2$ User's Guide. 2nd ed. Cary, NC: SAS Institute Inc.

Shaiful, A.A.A., 1992.The scope of biotechnology in livestock nutrition in the developing countries. Proceedings of an International symposium held at the institute of Basic Animal Sciences, Faculty of Agriculture and Horticulture, Humboldt-University of Berlin October 1992. pp ,26-35.

Shehu, B.M., J.O. Ayo, B.A. Ayanwale, E.Z. Jiya and D.N. Tsado, 2014. Growth performance and nutrient digestibility of weaned rabbits fed diets supplemented with varying levels of baker's yeast (Saccharomyces cerevisiae). Journal of Agricultural and Rural Development, 17:16191627.

Shrivastava, A.K., K.K. Tiwari, R. Kumar and R.R. Jha, 2012. Effects of feed additives on body weights at different ages in rabbit. Scholarly Journal of Agricultural Science, 2: 277-282.

Simonova, M.P., A. Laukova, L. Chrastinova, I. Placha, V. Strompfova, K. Z. Cobanova, Formelova and M. Chrenkova, 2013. Combined administration of bacteriocin-producing probiotic strain Enterococcus faecium with Eleutherococcussenticosus and their effect in rabbits. Polish Journal of Veterinary Sciences, 16: 619-627.

Thanh L.P. and U. Jamikorn, 2012. The effects of probiotics supplement (Bacillus subtilisandLactobacillus acidophilus) on feed efficiency, growth performance and faecal consistency index of weaning rabbits. In: Proceedings of the 50th Kasetsart University Annual Conference, Kasetsart University, Thailand from January 31 - February 2, 2012. 1. Pp, 136-43.

Tokic, V., M. Lazarevic, Z. Sinovic and A. Tokic, 2007. The influence of different feed additives to performance and immune response in broiler 
chicken. ActaVeterinaria (Beograd), 57: 217 229.

Witherspoon, L.R. and S.E. Shuler, 1984. Estimation of free thyroxine concentration: clinical methods and pitfalls. J. Clin. Immunoass, 7: 192-205.

Yamani, K.A., H. Ibrahim, A.A. Rashwan and K.M., El-Gendy, 1992. Effects of a pelleted diet supplemented with probiotic (Lacto-Sacc) and water supplemented with a combination of probiotic and acidifier (AcidPak 4 Way) on digestibility, growth carcass and physiological aspects of weanling New Zealand White rabbits. J Appl Rabbit Res,15:1087-1100.

Yang, Y., P.A. Iji, A. Kocher, L.L. Mikkelsen and M. Chotc, 2007. Effects of mannanoligosaccharide on growth performance, the development of gut microflora, and gut function of broiler chickens raised on new litter, 16: 280288.

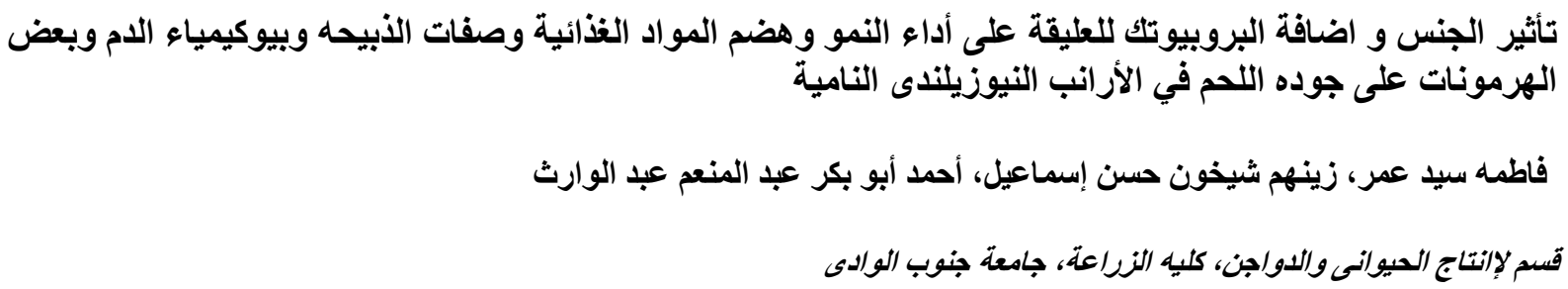

اجريت هذه التجربه لتقييم تاثير اضافه مستويات مختلفة من البروبيوتلك والجنس علي مظاهر النمو و هضم المو اد الغذائية ومو اصفات الذبيحه

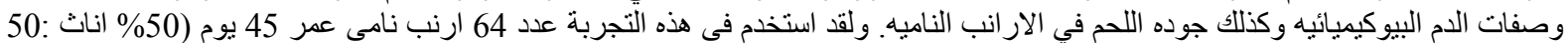

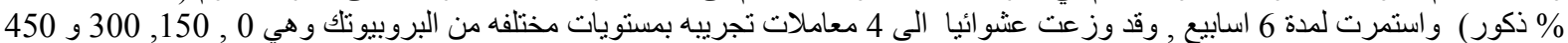

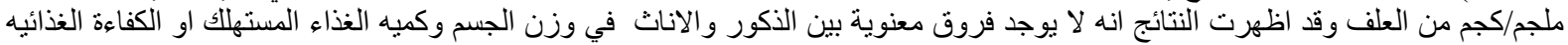

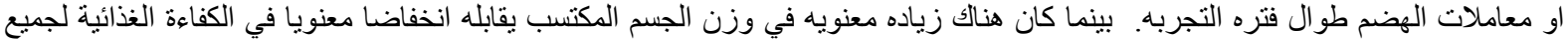

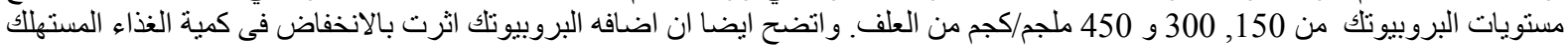

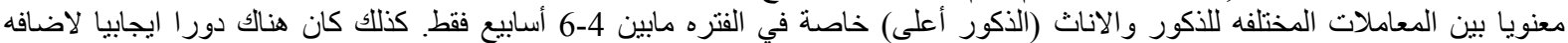

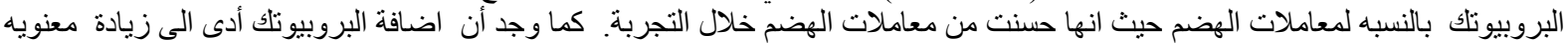

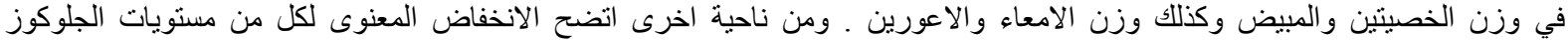

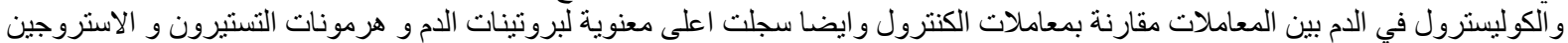

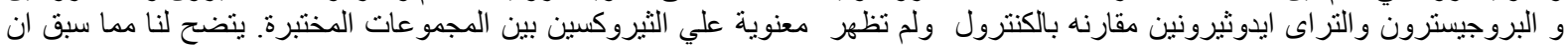

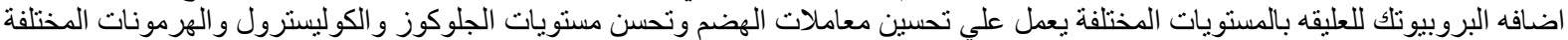
فى ذكور واناث الار انب النيوز لاندي الناميه. 